\title{
CST6 wt Allele
}

National Cancer Institute

\section{Source}

National Cancer Institute. CST6 wt Allele. NCI Thesaurus. Code C51344.

Human CST 6 wild-type allele is located within $11 q 13$ and is approximately $2 \mathrm{~kb}$ in length. This allele, which encodes cystatin M protein, is involved in the inhibition of cysteine proteases. CST 6 gene expression is down-regulated in certain cancers such as breast carcinomas. 